\title{
LXII. On Mr. Bennet's Electrometer
}

\section{Ez. Walker Esq.}

To cite this article: Ez. Walker Esq. (1813) LXII. On Mr. Bennet's Electrometer , Philosophical Magazine Series 1, 41:182, 415-416, DOI: $10.1080 / 14786441308638772$

To link to this article: http://dx.doi.org/10.1080/14786441308638772

曲 Published online: 27 Jul 2009.

Submit your article to this journal

Џ Article views: 2

Q View related articles $₫$ 
did not appear to have the slightest effect on. its external characters.

It is totally impossible to investigate the quantity of oxygen in ammonid by direct experiments on the amalgam of its base; I shall hereatter proceed to relate some experiments made in order to ascertain it. The whole of our knowledge of the base of ammonia, that problematical and yet in every respect highly interesting substance, consists almost entirely in our being assured of its existence under certain circumstances.

[To be continued.]

1.XII. On Mr. Bennet's Electrometer. By Ez, WALKEr, Esq.

To Mr. Tilloch.

Dear Sir, - I no not remember to have seen any further account of the properties of Mr. F'ennel's Electrometer, than what the inventor has given us in the Philosophical Transactions for 1786 , which relates mostly to its extreme sensibility, in distinguishing small quantities of electricity. This instrument, however, bas other properties, which merit the attention of electricians.

An excited surface being brought near the top of this instrument, but not so near as to produce as park, the groldleaves will diverge in the same state of electricity as the excited surface; but as soon as it is removed, the goldleaves will collapse, and instantly diverge again in a contrary state; and these changes will take place every time that the excited surface is moved to and from the cap of the instrument.

There is no work on electricity with which I am acquainted, that takes notice of these phanomena, nor was it till after I had made many experiments that I could form any thing like an explanation.

But atier I found that there is a positive and a negative point, at every interruption of an electric circuit, or that the top plate of the instrument is negative, at the same time that the gold-leaves are positive, the phænomena no longer appeared inexplicable.

Place a slip of leat-gold, about half an inch long and one-tenth of an inch broad, upon the top of the instrument, and let one end of it be tixed to the plate, with paste, gumwater, or varnish ; then, if a glass tube, excited by rubising it witb silk, be brought near the top of the electrometer, 


\section{Case of Hydropholia cured in India by Bleeding.}

the slip of leaf-gold will stand erect, being attracted by the excited tube; which shows that the tep plate is postessed of the resinons $r$ nogatuve electrucity; and the gold leaves within the glass will at the same tume diverge with the vitreous or posiive electricity, the same as the excited tube.

But as son as the excited surface is remoreti, the goldleaves will cullapse and instantly diverge again, and when examined will be found to have recerved the reminous electricuty, the top plate still pussessing the same fluid.

Now, as prart of the vitreous huid has been repelled from the cap thruagh the gold-leaver and tin. iol mot the earth, the cap must necessarily possess lcos of the vitreous than its natural share; and consequently, when the excined tube is removed, the resinnus flud in the cap will attract the vireous out of the grold-leaves: but this being too small a quantity to rustore the equilibrium, the cap will still contimue in a negative state, and communicate the negatuve or resinous fluid to the gold-leaves, which will cause them to diverge a stcond time; and as the cap is insulated it will contmue electrified for some time after, if the instrument be a large one *

This experiment also shows, that electricity by induction or position does not vanish ds suon as the excited surlace is removed, though Professor Robison and other writers on electricuty are of a contrary opinion.

$$
\begin{aligned}
& 1 \mathrm{am}, \text { dear sir, } \\
& \text { Your obedient servant, } \\
& \text { E. W WLKER. }
\end{aligned}
$$

LXIII. Cuse of Hydroph lia cured in India by Bleeding. By John Shoozbred, M.D. From the Supplement to the Calculta Government Gazette, June 8, 1812.

$$
\text { [Concluded from p. 365.] }
$$

\section{REMARKS.}

$\mathrm{O}_{\mathrm{N}}$ hearing that a recovery from hydrophobia has been efreted in the short space of two hours, by the single remedy of blood-letting, a doubt may probably occur to a person acquainted with the previous history of this formidable malady, and the nearly' uniform failure of all attempts hitherto made for its cure; whether the disease now said to be cured, was in reality a genuine case of bydrophobia,

- The glass of an electrometer for these expcriments should not be less than four inches in dianieter, and nine or ten inches high.

produced 